\title{
EGFR NM_005228.3:c.2246_2260del15
}

National Cancer Institute

\section{Source}

National Cancer Institute. EGFR NM 005228.3:C.2246 2260de115. NCI Thesaurus. Code C98571.

A deletion of 15 nucleotides from the coding sequence of the EGFR gene from position 2246 through 2260. 